\title{
Viral Marketing and E-Word of Mouth Communication in Social Media Marketing
}

\author{
H. Hendrayati \\ Universitas Pendidikan Indonesia \\ Bandung, Indonesia \\ P. Pamungkas* \\ Universitas Pendidikan Indonesia \\ Bandung, Indonesia \\ *putra.pamungkas@upi.edu
}

\begin{abstract}
Social media users in Indonesia are increasing by the speed of internet in Indonesia. Business stakeholders use this as one of the things covered. Opportunities to get potential target become one of the reasons of appear social media advertising concepts. As a new alternative to media promotion, social media needs to be assessed through theoretical computations. The features and systems needed in social media need to be supported by an understanding of the theories. Therefore it is necessary to do a theoretical study that can analyze the phenomenon of social media advertising in. This is important given the enormous opportunities on social media as an alternative to marketer innovation. One form of social media that develops is viral marketing and e-WOM. Where there are two concepts in viral and e-WOM that are divided into two which are negative viral and positive viral, in accordance with the factors inflicted against the company or product. With the understanding of the theory then the function of social media can be utilized by the company as one of the promotional media. For consumers, it acts as a source before making a decision. Thus, it is expected that the optimization of the use of social media as a media campaign to be more developed.
\end{abstract}

Keywords-Viral Marketing; E-WOM; Social Media Marketing

\section{INTRODUCTION}

Information technology is an important media that play a role in decision making. Quick information will help marketers to win the competition. Advances in digital telephone networks, interactive cable television, personal computers, online services and the Internet, make information faster and easier to obtain [1]. Things that happen in the digital world become one of the most interesting public consumption to follow. In developing the concept of marketing today, online marketing becomes a consequence of the development of information technology.

[2] has provided a logical proposition on how behavior patterns influence the marketing concept. In this study we gave a concrete picture of how marketing paradigm shift becomes the most significant variable in the changing of concept and strategy of marketing. The tendency of millennial consumer behavior patterns that are most adaptable to the development of technology, became one of the company's strong reasons for switching to the digital marketing era.

One of the bargaining of the digital world is the widespread use of social media. Almost all individuals have personal social media as access to information both privacy and public. According to the latest data released We Are Social as of August 2017, the number of global Internet users now touches 3.8 billion with penetration 51 percent of the total population in the world. This means there are great opportunities that are spread in social media (facebook, Twitter, Instagram etc.) that can be used as a distribution channel of information products and services offered.

Social media is one of the interconnecting instruments between individuals online that allows direct interaction between one party with other parties indefinitely space and time through technology. Persuasive power of social media as one element of marketing to be one of the main drivers of the emergence of the term Social Media Marketing.

The use of social media as a marketing communication medium attracts researchers to enter the realm of marketingbased social research media, the result [3], states that 68.5 percent of internet marketing research has been published in the last eight years.

Marketing social media became one of the new marketing trends that are more desirable by companies especially for start up. This communication medium becomes one of the most attractive access as an alternative new marketing strategy. When compared with traditional marketing strategies, then the tendency of companies to use social media as one of the media marketing is high enough. In the implementation of mareking social media will produce a new thing that became known as viral marketing and e-Word of Mouth Comunication (eWOM), that is content of implication from digital marketing which then considered become influencer to a consumer decision and influencer to value marketed product.

Based on the description above, researchers interested in studying the use of social media as a promotion channel in 
product to arrive at the consumer. The message means a transfer of information, to further follow up customer decision making.

In particular it can be said that the function of advertising in the marketing component is as a tool or media "propaganda creation needs" of consumers. Advertising is the means by which the producer makes the interest and the need for the recipient of the advertising message to become necessary for the advertised goods or services. In addition, the function of advertising is also a tool to deliver information of products and services offered, such as drug advertising other than as a media product introduction, advertising in this form is used as a messenger of procedural about how the functions and procedures of its use.

\section{Internet marketing}

There are three main components that form the concept of information technology, namely:

- Computer.

- Communication.

- Content.

As a handle for marketing on the Internet will be a lot to play on content information offered [6]. We need to realize together that actually the main service / product that is possible on the Internet is Advertising / Promotion \& transaction.

In line with this then obviously the function of internet marketing is to change the interest of online visitors to become offline buyers. There is a transactional message used by social media as the main concept in the world of internet marketing. That the success of a marketing is the occurrence of real transactions after creating relationships online.

The benefits of internet marketing in the marketing world is big enough to be at least one of the important channels in the concept of promotion and marketing. According to [7] internet marketing has five major advantages for companies that use it. First, both small companies and large companies can do it. Second, there is no real limit in advertising space when compared to print media and broadcast media. Thirdly, access and information searching is very fast when compared to a flash letter or even a fax. Fourth, the site can be visited by anyone, anywhere in this world, anytime. Fifth, shopping can be done more quickly and alone.

\section{Social media}

Social media is one of the interconnecting instruments between individuals online that allows direct interaction between one party with other parties indefinitely space and time through technology. [8] define social media as an internetbased application group that builds on the foundation of Web 2.0 ideology and technology, and which enables the creation and exchange of user generated content.

In general, social media has a communicative nature, this is the right strategy is where the users of this service can provide as much detail as possible to the users. In addition fast response is also one of the advantages often used in promotion with social media [9]. enough to give a significant influence in the process of interaction between producers and consumers. One of the main functions of advertising is how to convey the message of a 
leads businesses to get immediate results from

According to [10], social media is also now a means or activity of digital marketing, such as social media maintenance, social media endorsement and social media activation. Therefore, social media is now one of the services offered by digital agency.

Shifting the function of social media from its origin is only limited to the means of interaction, become a business media is one of the development of the paradigm of thinking business concept in the digital era. Social media becomes a useful information distribution channel for the company as one of the intermediaries of the conceptual content of business messages delivered to the user. The millennial market is one of the potential business markets, because the average social media user is included in the upper middle market segment.

Spend of funds for social media applications and operations is one proof that this segment is potential to be worked on in the field of business and broadcasting. A wide reach and a large market share is one of the reasons social media can be used as an effective promotional channel. The Flow of Social Media is indeed out of control and bursting with this social media has become very important to reach the target market and engage with potential customers, this medium does not need to spend big [11].

\section{METHOD}

The purpose of this research is to know the devel-opment of Social Media Advertising concept. This study focuses on actual issues that are ongoing and become a trend in the marketing world that is via so-cial media merchandise. The effort of this study is to describe a phenomenon or event (phenomenon) occurring at the present time studied with theories, litharicas and other studies related to this concept. the research method used is literature study.

In order to analyze marketing via social media in Indonesia under natural conditions, the method of data retrieval used is by browsing and literature study. Literature analysis is used to see how far the effectiveness of promotion via social media, because in the current digital era social media is one of the most effective promotional media for both new companies, and companies that have advanced.

\section{RESUlTS AND DisCUSSION}

Internet marketing is one of the tools in marketing communication that is currently widely used as a new media tools in the marketing world, one of the way is by exploiting the popularity of social media as a medium of promotion.

According to [12], online marketing (e-Marketing) can be categorized into several elements with each method having specific goals about the advantages and disadvantages. The benefits derived from e-Marketing include:

- Branding: Products, services, company logos, and offers can be displayed visually, even now more vibrant with streaming audio and video installed through the internet.

- $\quad$ Direct Response: e-Marketing offers speed. Users can respond easily and quickly. Of course this promotional activities and advertising through the internet.

- Targeting: With the technology used (such as rss, mailing lists, forums, or certain website codes) can target users or potential customers.

- Tracking: The most powerful element of eMarketing is, almost anything can be tracked and can be seen instantly. This means, if there is something in the system that does not work, you can handle it.

- Return on Investment: Since the tracking power is so good, you can ensure that your capital can return. By being able to determine how many people click on banner ads or email links, business owners can easily calculate the return of investment capital.

- Inexpensive (not expensive) e-Marketing, especially email and buy keywords (keywords) on the internet search engine is relatively cheap, it can even be said very cheap. Email fees are usually already incorporated with the cost of connection to the Internet Service Provider (Internet Service Provider) who entered the service. Keyword purchases can be made to search engine companies like Google and Yahoo.

The user of internet marketing is not only based on mainstream platform just like Google and Yahoo, but then social media which in fact is private domain can be used as one of important intrument in marketing and business. The role of social media for business is as follows:

- Social media is an easy way to find out more about customers

- Social media helps target consumers more effectively.

- Social media helps find new consumers and expand market targets.

- Developing market targets and one step ahead of competitors.

- Share information faster with social media.

- Social media helps generate new consumer candidate list.

- Social media enhances brand awareness and promotion with minimal costs.

- Closer to the consumer through social media.

\section{A. Strengths and weaknesses of internet marketing}

As a media / tools in marketing, of course the internet has various Strengths and weaknesses that must be faced. Internet users in this case can be meaningful marketers and also can be meaningful to consumers. In the context of internet marketing, the interaction that occurs between the marketer and the 
promotion of many people will talk about what has been promoted in social media [9].

Social Impact Theory was introduced by Bibb Latane in 1981 by being actively involved in trying to understand the influence of others on social behavior. According to Bibb Latane who cited of [9], Social Impact Theory is one practical application that can be used as a strategy by partici-pating actively in social media such as twitter, Face-book, LinkedIn and so forth.

The cited [9] on SIM (Strategic Impact Models) in relation to social media is described as follows: The Strategic Impact Model illustrates that different causes and interventions are combined and implemented in an integrated manner with accompanying management activities. Further, the implementation is done through social media that has become part of the promotion tool with global reach and the cost is relatively cheap. Social media pro-vides opportunities for direct interaction and building relationships quickly, freely and indefinitely space and time. Social strategy is done on social me-dia by doing impact and social impact strategy with reference to message delivered on social media.

In this context, it is clear that the use of social media as a marketing communication tool is one of the important elements in the business base in the current era. Information technology has become one of the important concepts in the world of global marketing. The most important rule of these models of social media advertising is to get an effective marketing concept on mass media with the effort to minimize costs.

\section{Effectiveness of ads in social media}

The key to get success in advertising is to develop an interesting message that will reach potential customers in an adequate area at the right time. According to [13], the minimum level of effective advertising has the following considerations:

- Advertising should extend marketing strategy. Ads can be effective when they match other elements of a well-directed and integrated marketing communications strategy.

- Advertising should include the consumer's point of view. Given that consumers buy product benefits, not attributes.

- Good advertising should be persuasive.

- Ads should find a unique way to break through the ad crowd. It means that advertising must be creative.

- Good ads never promise more than what can be given. The bottom line is an ad explains honestly.

- A good ad prevents from excessive strategy. The purpose of advertising is to persuade and influence. Not to make nice and make funny. The use of ineffective humor results in people only remembering humor alone without remembering the message. understand the influence of individuals against other individuals. The message of persuasion on social media for the 
While the effectiveness of advertisement in social media can be measured by using EPIC Model approach developed by AC Nielsen. [14] describes the EPIC models with four dimensions:

- Empathy. In general, social media users understand the contents of the information submitted in social media advertising that initially does not have an emotional meaning for users of social media. Consumer empathy needs to be improved through advertising to be interested in understanding the contents of an advertisement issued by the company as a consumer's fulfillment. By promoting through advertising indirectly will increase a person's desire to understand the contents of the ad and find the ad.

- Persuasion. Persuasion is a change that occurs to the trust of social media users, attitudes and wishes behave that caused a promotional communication from social media. The submitted ads need to be easy to understand and attract consumer interest in the increased product and will arise feelings want to know more about a product that raises the attraction for consumers.

- Impact. The desired impact of promotional results in social media is the increased knowledge of social media by looking at the frequency of activity of users opening social media and how often to visit social media. By using attractive ads through practical media such as social media will increase consumers' desire to search for information, and try products that interest them. Then, these ads will affect consumers to make product selection.

- Communication. Communication emphasizes the understanding of social media users and the power of impression left behind from the information provided on the ad.

\section{Viral marketing}

In today's digital world, the use of social media is quite important in the concept of marketing, social media can be a substitute for some traditional media communications because social media users active to answer the needs of society compared to traditional media [15]. Many interesting variables are the study of the world of social media marketing. The table above explains a lot about the implementation of social media marketing. With a wide reach and ease of access to social media, the effectiveness of marketing through social media becomes one of the advantages when compared with traditional marketing techniques. Although the qualitative number of follower (Follower) a social media company that does not reflect the number of buyers, but the quantification of the number of followers reflects the high brand equity of a brand [15].

[16] proves that social media marketing communications have a significant effect on each behavioral component, but the average value is decreasing every successive step. This finding fits the principle of a sales funnel developed through traditional advertising and verifies that SNA produces the same attitude among young consumers.

The social impact of Social media function that is to understand the influence of individuals against other individuals. The message of persuasion on social media for the promotion of many people will talk about what has been promoted in social media [9]. Social Impact Theory was introduced by Bibb Latane in 1981 by being actively involved in trying to understand the influence of others on social behavior. According to [9], Social Impact Theory is one practical application that can be used as a strategy by participating actively in social media such as twitter, facebook, LinkedIn and so forth.

Reflecting from that then in the implementation of social media use as a marketing communication tool aims to be an important concept called "Viral Content". In the language of content creation viral marketing is a manipulative effort to create a brand equity of a product offered, in the language of marketing a thing that 'Viral' is enough to provide a bargaining effect for a product that is being marketed so that some litelatur mentions the "Buzz" marketing for this viral terminology.

Viral marketing is something that has been created by the company itself to promote their products, in the hope that people who see the campaign will be so impressed that they will deliver the message to their friends and family. The expected outcome of viral marketing is word of mouth (WOM) marketing, which is when people tell others about great new videos on YouTube, or apps on Facebook.

Hundreds of companies, big and small, came up with clever ways to promote themselves, by posting videos on YouTube, finding adver games, and even using 'plug agents" that spread buzz about new products or sales through their products. own social network A study by Magazine Inc. recently reported that 82 percent of the fastest-growing private companies use such initiatives.

No one denies this viral marketing concept. People are happy and proud to send their friends something funny, or tell them about new products they know. But they are just as quick on sending bad news as to a product's contents, so make sure a company is able to manage the two sides of the currency from this viral transmission. Because in addition to a positive impact, viral marketing can also be negative if the later in viralkan is a negative contense of a company. For example, how the medio 2016, Sari Roti, in Indonesia must experience negative content from the concept of digital viral so that it affects the decrease of its sales turnover.

[17] offers four important tips for implementing viral marketing successfully:

- Use tactics to build awareness and experimentation. Explain what this viral concept wants to accomplish on the product image that consumers want to build, and use the most appropriate technique to achieve the goal. This is a great and inexpensive way to get customer feedback, and the company will get contact details 
WOM, such as elaboration probability model (ELM) and heuristic-systematic (HSM) model.

This result is in line with the ELM research findings on the effectiveness of persuasive messages in the context of social media [20]. The authors of this study continued the Cheung and Thadani studies by reviewing the e-WOM research literature between 2011 and 2014. Among the 45 documents identified, 22 discussed the introduction of persuasive e-WOM messages, while eight studied the impact of e-WOM communication in cyberspace. More paper is considered as valence (positive or negative) of e-WOM messages.

Several studies apply planned behavioral theories and technology acceptance models [20] [21] [22]. It proves that eWOM studies are still receiving significant attention in the academic world, especially in marketing. To answer the purpose of this study, the authors critically examine previous research and categorize prospective predecessors of persuasive e-WOM messages in relation to the acceptance of information and intent to use online reviews. In the following section the author discusses some antecedents of a persuasive e-WOM message to develop the research hypothesis.

The unique interactive nature of cyberspace has provided online users with unprecedented accessibility to information about products and services, the ability to exchange ideas with consumers and other friends, or even companies and to compare prices and quality in various ways. This interaction is done through blogs, instant messages, forums, online communities, social networking sites and so on [23]. With a wide range of messages, social media users engage and exchange information through various channels defined as social media, such as blogs, microblogging (Twitter), social networking sites (Facebook) and video sharing sites (YouTube). It is not surprising that consumers exchange product information online with other consumers.

By sharing experiences and personal feelings about products and services, online users tend to receive and use online information in their decision-making process. Unlike electronic word of mouth (e-WOM) word of mouth (eWOM) can include positive and negative reviews made by former, actual and potential customers about products and services over the internet at the right time [18]. Online customer reviews give potential customers important information about whether to buy products / services. It was reported that more than 74 percent of travelers use online reviews / comments sent by other travelers to make decisions when planning a trip [24]. It is therefore evident that online reviews have become an important source of information.

Despite significant managerial and academic attention to eWOM, several research studies have directly tested the potential determinants of e-WOM messages and the credibility of e-WOM communication perceived in the context of social media. The authors use statistical techniques to test potential eWOM attributes and measure their impact on information reception and intent to use online reviews. This study aims to measure perceptions of message recipients about the credibility of e-WOM messages. posted on discussion forums or rating sites are the main focus of most e-WOM studies. In terms of theoretical basis, their review indicates that dual-route information processing is the most commonly used theoretical model for the impact of e- 
This study also aims to examine critically the determinants of persuasive e-WOM messages and how message recipients want to receive and use e-WOM messages. The importance of this study is to identify the effectiveness of e-WOM messages and their impact on the intention to receive and use these messages. In addition, this research will provide insightful guidance for marketers with practical implications for social media communications. In this study the authors identified previous e-WOM research and critical factors in e-WOM communication. An integrated conceptual template was created to study the persuasive e-WOM effect on the recipients' desire to receive and use online information; theoretical and practical implications are included in the journal.

\section{F. Empirical assessment of viral marketing and e-WOM in the empirical world}

Viral marketing and e-WOM become a new phenomenon in the world of digital marketing. Many empirical examples of marketing where a product and service can suddenly reap huge profits or even a big loss due to the influence of viral marketing. In the viral marketing world, we recognize two viral content concepts that are viral and viral negative. Viral positive is a viral content that then brings a positive impact to the company those impacts on the in-crease in sales or brand of a product or service over the good concept in its positive news coverage. While viral negative is a viral content that actually then bring a negative impact on the sale or brand of a product or service.

One example of viral marketing and e-WOM positive is the increasing public interest in purchasing Bomber jackets as a viral implication of the Indonesian President who uses the jacket. In addition, the impact of agenda 212 as a best movement of Mus-lims makes the concept of 212 Mart and 212 products become consumer choice. The bustling netizen news about Makuta's sponge, caused a massive in-crease in Makuta's sales turnover as it is a part of the viral positive.

In contrast, the negative viral and e-WOM that hit United Airlines put United Airlines shares down, and the loss was estimated at IDR 13 trillion as a re-sult of the viral video of the airline officer while dragging passengers on board. In addition, a similar impact in natural salt traders in the capital city of Jakarta who must bear the decline in turnover after the viral incidence of salt mixed glass shard that became crowded netizens in the world social media.

Based on this concept of viral marketing and e-WOM is theoretically divided into two namely the viral and e-WOM created by the company and there is also a viral that suddenly crowded by netizens by itself. The trait is if the negative concept of viral tendency is as the content that occurs suddenly, while for viral positive content, sometimes compa-nies deliberately create the concept.

\section{CONCLUSION}

Utilization of social media as an alternative promotion should be optimized well by considering the potential and opportunities in this internet era is very large. Traditional ads with social media are more effective because they can drive traffic and sales. The use of social media as a means of promotion even offers long-term value. With social media the visual concept will push our products to be seen by more others.

Doing business by exploiting the beauty of visual or audio visual content will make prospective customers decide to immediately buy business market-ers products. The key to successful advertising is to develop an interesting message that will reach potential customers in an adequate area at the right time. Therefore the selection of features on social media that is true and interesting will give a positive impact in the effectiveness of promotion through social me-dia. The arrival of information messages to prospective buyers, two-way interaction between marketers and potential buyers and turning interest and information into consumer purchase decisions is the main core social media advertising function.

But from some of the advantages that arise from the concept of "Viral Marketing" and "e-WOM" companies should start choosing how this concept is really applied carefully, because the two sides of the currency effect generated by this concept. Every-thing can circulate quickly and unpredictably, mean-ing that in addition to positive values that can quick-ly spread to the public, negative corporate contents and negative impressions from one consumer to the company will easily affect the company image.

\section{REFERENCES}

[1] Paul, P. 1996. Marketing on the internet. Journal of Consumer Marketing 13(4): 27-39.

[2] Valentin, E.K. 1992. How behavioral viruses afflict market strategy. Journal of Services Marketing 6(1): 65-75.

[3] Pomirleanu, N., Schibrowsky, J.A., Peltier, J. \& Nill, A. 2013. A review of internet marketing research over the past 20 years and future research direction. Journal of Research in Interactive Marketing 7(3): 166-181.

[4] Andriawan, I. 2016. Fenomena Instagram sebagai media pemasaran. Doctoral dissertation. Bandung: Fakultas Ilmu Komunikasi UNISBA.

[5] Kotler, P. \& Susanto, A.B. 2001. Manajemen pemasaran di In-donesia (Buku 2). Jakarta: Salemba Empat dan Pearson Education Asia.

[6] Supradono, B. 2007. Strategi pemasaran lewat Internet (Cybermarketing). Value Added Majalah Ekonomi dan Bisnis 4(1).

[7] Widodo, S. 2002. Pengguna internet Indonesia mencapai 4,2 juta user. Retrieved from http://www.detikinet.com/berita/2002/01/03/20020103174809.shtml. Accsessed 25 December 2017.

[8] Kaplan, A.M. \& Haenlein, M., 2012. Social media: Back to the roots and back to the future. Journal of Systems and Information Technology 14(2): 101-104.

[9] Umami, Z. 2015. Social strategy pada media sosial untuk promosi pariwisata Daerah Istimewa Yogyakarta. In-teraksi: Jurnal Ilmu Komunikasi 4(2): 195-201.

[10] Cahyono, A.S. 2016. Pengaruh media sosial terhadap peru-bahan sosial masyarakat di Indonesia. Jurnal Publiciana 9(1): 140-157.

[11] Putra, T.K., Hartanto, D.D. \& Sylvia, M. 2013. Perancangan promosi IN_NI PIZZA Surabaya dengan pendekatan sosial media dan pendukungnya. Jurnal DKV Adiwarna 1(2).

[12] Rahadi, D.R. 2017. Sosial media marketing dalam mewujudkan emarketing. KNTIA 4.

[13] Nasution, F.S.P. \& Suyanto, A. 2016. Efektivitas iklan media sosial menggunakan Epic Ac Nielsen pada operator seluler di Indonesia. eProceedings of Management 3(3).

[14] Febrina Syah, A. S. (2016). efektivitas iklan media sosial menggunakan EPIC AC Nielsen pada operator seluler di Indonesia. e-Proceeding of Management, 2667. 
[20] Teng, S. \& Khong, K.W. 2013. Conceptualising persuasive messages using elaboration likelihood model in a social media perspective. In Second Annual International Conference on Consumer Research and Marketing: Frontiers of Theory, Method and Practice, CMMU, Bangkok: 1-20.

[21] Benlian, A., Titah, R. \& Hess, T. 2012. Differential effects of provider recommendations and consumer reviews in e-commerce transactions: An experimental study. Journal of Management Information Systems 29(1): 237-272.

[22] Cheng, H.H. \& Huang, S.W. 2013. Exploring antecedents and consequence of online group-buying intention: An extended perspective on theory of planned behavior. International Journal of Information Management 33(1): 185-198.

[23] Goldsmith, R.E. \& Horowitz, D. 2006. Measuring motivations for online opinion seeking. Journal of Interactive Advertising 6(2): 2-14.

[24] Gretzel, U. \& Yoo, K.H. 2008. Use and impact of online travel reviews. Information and Communication Technologies in Tourism: 35-46. 